\title{
Inhibition of proliferative and suppressor responses in the autologous mixed lymphocyte reaction by serum from patients with systemic lupus erythematosus
}

\author{
H. A. F. STEPHENS, ${ }^{1}$ PENNY FITZHARRIS,${ }^{2}$ R. A. KNIGHT, ${ }^{2}$ AND M. L. \\ S N A I T H ${ }^{1}$ \\ From the ${ }^{1}$ Department of Rheumatology, University College Hospital, Gower Street, London WC1, and the \\ ${ }^{2}$ ICRF Human Tumour Immunology Unit, University College Hospital Medical School, University Street, \\ London WC1
}

SUMMARY Serum from patients with systemic lupus erythematosus (SLE) prevents the proliferative response of normal $\mathrm{T}$ cells when stimulated by autologous or allogeneic non- $\mathrm{T}$ cells. The abrogation of proliferation in an autologous mixed lymphocyte reaction (AMLR) with SLE serum is associated with a lack of suppressor $\mathrm{T}$ cell generation. Fractionation of SLE sera on sucrose gradients reveals an $18-12 \mathrm{~S}$ peak of Raji cell binding material. Fractions with an $\mathrm{S}$ value of $\leqslant 12 \mathrm{~S}$ show inhibitory activity in an AMLR.

Systemic lupus erythematosus (SLE) is an autoimmune disease characterised both by an excess of circulating immunoglobulins ${ }^{1}$ and by the production of antibodies normally immunogenically quiescent. Antigens abnormally recognised in SLE include nuclear proteins, ${ }^{2}$ nucleic acids, ${ }^{3} \beta-2$ microglobulin, ${ }^{4}$ and T lymphocyte surface molecules. ${ }^{5}$

Normally the production of antibodies by B lymphocytes is influenced by the activity of $T$ lymphocytes. Helper T cells (Th) increase B cell antibody production, while suppressor $\mathrm{T}$ cells (Ts) reduce it. The abnormal antibody production in SLE may therefore reflect an intrinsic B cell defect, malfunctioning of $T$ cell control of B cell activity, or both. We report here that lupus sera contain an activity which inhibits the generation of Ts cells in normal donors.

The autologous mixed lymphocyte reaction (AMLR) is a proliferative response of normal T cells when stimulated in vitro by autologous non-T cells. ${ }^{6}$ In this response $T$ cells are generated which suppress the proliferative and cytotoxic responses of fresh $T$ cells $^{7}$ as well as inhibiting $\mathrm{B}$ cell antibody production. For example, AMLR primed $T$ cells suppress the proliferation of fresh $T$ cells stimulated by either autologous or allogeneic non-T cells. Antibody pro-

Accepted for publication 30 September 1981 . Correspondence to H. A. F. Stephens. duction in vitro, induced both polyclonally by mitogen and specifically by antigen, is also suppressed by AMLR primed T cells. ${ }^{8}$

Cells from SLE patients, however, fail to proliferate and generate Ts cells in an AMLR. ${ }^{7}$ Cell mixing experiments with cells from normal donors and SLE patients have suggested that the deficiency in the SLE AMLR response lies at the responder $T$ cells level. $^{9}$

T cells from SLE patients also fail to develop normal levels of suppressor activity after stimulation with concanavalin-A (con-A), ${ }^{10}$ a deficiency that is reinforced if the con-A response is performed in autologous lupus serum. ${ }^{11}$ The inability of SLE patients to respond in an AMLR, together with the absent suppressor response to con-A, has led to suggestions that deficient suppressor control contributes to the abnormal B cell activity characteristic of the disease. ${ }^{10}$

In this study we show that sera from SLE patients inhibit the proliferative and suppressor responses in the AMLR, using cells from normal donors. A preliminary characterisation of the inhibitory factor shows that cytophilic IgM anti-T cell antibodies are not responsible. These data suggests that any inherent deficiency in Ts cells or their precursors in SLE patients may be exacerbated by factors in their serum. 


\section{Patients and methods}

Patients. Seven consenting female patients with systemic lupus erythematosus were studied. All patients fulfilled 4 or more of the American Rheumatism Association's criteria for the classification of SLE. Serum samples were obtained from patients and normal laboratory staff and stored at $-50^{\circ} \mathrm{C}$. Age, treatment and disease activity of the patients are recorded in Table 1 . Disease activity was graded according to the UCH/Middlesex Hospital criteria $^{12}(1=$ inactive, $2=$ moderately active, $3=$ severely active). Circulating immune complexes (CIC) were measured by polyethylene glycol (PEG) precipitation $^{13}$ and the erythrocyte sedimentation rate (ESR) by the Westergren method. Antibodies to DNA were measured by a commercially available kit (the Radiochemicals Centre, Amersham, England), which measured binding largely to double stranded DNA. A total peripheral blood lymphocyte (PBL) count is included in Table 1.

Serum fractionation. Sera from normal donors and SLE patients were fractionated by centrifugation over $10-40 \% \mathrm{w} / \mathrm{v}$ sucrose gradients at $100000 \mathrm{~g}$ for 18 hours. $1 \mathrm{ml}$ of test serum or $1 \mathrm{ml}$ of $\mathrm{a}^{32} \mathrm{P}$ labelled rRNA marker solution (kindly donated by Dr M. Fried) was layered over a total gradient volume of $14.8 \mathrm{ml}$. After centrifugation $1 \mathrm{ml}$ fractions were collected and their sucrose concentration and radioactivity measured. Individual fractions from the serum gradients were dialysed exhaustively against phosphate buffered saline (PBS, $\mathrm{pH} \mathrm{7 \cdot 2)}$ and their absorbance at $280 \mathrm{~nm}$ measured (Pye Unicam SP6-500 UV spectrophotometer, Pye, Cambridge, England). Protein concentration was calculated relative to the extinction coefficient of IgG. Fractions were then assayed in the Raji cell radioimmunoassay, and for inhibitory activity in mixed lymphocyte reactions. $S$ values for the fractions were obtained by relating their sucrose concentration to those of the ${ }^{32} \mathrm{P}$ labelled rRNA subunits.

Raji cell radioimmunoassay. The assay procedure was a micromodification of the method described by Theofilopolous et al. ${ }^{14}{ }^{15}$ Briefly, $100 \mu$ l of Raji cells at a concentration of $5 \times 10^{6} / \mathrm{ml}$ in balanced salt solution (BSS) were dispensed into the roundbottom wells of a microtitre plate (Titertek, Flow Laboratories, Paisley, Scotland), $100 \mu$ l of test sera, diluted 1:10 in BSS were then added to triplicate wells. After a 45 -minute incubation $\left(37^{\circ} \mathrm{C}, 5 \% \mathrm{CO}_{2}\right.$ humidified incubator), the plates were spun, and the cell pellets washed 3 times in BSS. $100 \mu$ l of ${ }^{125}$ I labelled goat antihuman $\mathrm{F}(\mathrm{ab})_{2}$ (diluted to a concentration of $1 \mathrm{mg} / \mathrm{ml}$ in BSS containing $1 \%$ heat activated newborn calf serum) was then added to each well, and the incubation was continued for a further 30 minutes at $4^{\circ} \mathrm{C}$. The anti-immunoglobulin reagent was a kind gift from $\mathrm{Dr}$ A. R. Sanderson (Guy's Hospital, London) and had been purified by ion exchange and affinity chromatography. Radioiodination was performed by the chloramine $\mathrm{T}$ method. ${ }^{16}$ At the end of the incubation the plates were spun and the cells washed 3 times as described above. Washed pellets were transferred in $100 \mu \mathrm{l}$ volumes of BSS to LP2 tubes (Luckham Ltd, Burgess Hill, Sussex, England). Radioactivity was counted in a LKB-Wallac gamma counter (Model 128C Ultragamma LKB, Bromma, Sweden).

The results for individual sera are expressed as a percentage of counts per minute (cpm) bound by a standard SLE serum, as calculated by the following formula:

Raji binding unit $(\mathrm{RBU})=$

\begin{tabular}{lll} 
Test sera cpm bound & - & background $\mathrm{cpm}$ bound \\
\hline Standard sera cpm bound & - & background $\mathrm{cpm}$ bound
\end{tabular} 100

Table 1 Clinical, pathological, and therapeutic parameters of patients whose sera or cells were used in the study

\begin{tabular}{|c|c|c|c|c|c|c|c|c|}
\hline Patient & Age & $\begin{array}{l}C I C(\mu g / m l) \\
(\text { normal }<100) \\
P E G \text { pptn. }\end{array}$ & $\begin{array}{l}\text { C3 }(\mu \mathrm{g} / \mathrm{ml}) \\
(\text { Normal }= \\
860-1800 \\
\mu \mathrm{g} / \mathrm{ml})\end{array}$ & $\begin{array}{l}\text { ESR } \\
(\mathrm{mm} / \text { hour }) \\
(\text { normal } \leqslant 15)\end{array}$ & $\begin{array}{l}\text { DNA binding } \\
\text { (units } / \text { ml }) \\
(\text { normal } \leqslant 30)\end{array}$ & $\begin{array}{l}\text { Total } \\
P B L s / m l \\
\times 10^{8}\end{array}$ & Treatment & $\begin{array}{l}\text { Disease } \\
\text { activity }\end{array}$ \\
\hline 1 & 39 & 600 & 1422 & 107 & 25 & $1 \cdot 1$ & $\begin{array}{l}\text { Flurbiprofen } \\
(300 \mathrm{mg} / \text { day })\end{array}$ & 2 \\
\hline 2 & 46 & 125 & 729 & 65 & 20 & $0 \cdot 3$ & $\begin{array}{l}\text { Azathioprine (125 mg/ } \\
\text { day, prednisolone } \\
\text { ( } 5 \mathrm{mg} / \text { day) }\end{array}$ & 2 \\
\hline 3 & 21 & 400 & 640 & 77 & 130 & 0.9 & None & 2 \\
\hline 4 & 56 & 1189 & 1498 & 26 & 8 & $0 \cdot 8$ & $\begin{array}{l}\text { Prednisolone ( } 4 \mathrm{mg} / \mathrm{day}) \text {, } \\
\text { indomethacin }(150 \mathrm{mg} / \\
\text { day), aloxiprin }(2 \cdot 7 \mathrm{~g} / \mathrm{day})\end{array}$ & 2 \\
\hline 5 & 27 & $53 \cdot 7$ & 741 & 74 & 30 & 0.4 & $\begin{array}{l}\text { Prednisolone } \\
\text { (10 mg/day) }\end{array}$ & 2 \\
\hline 6 & 33 & $339 \cdot 2$ & 784 & 96 & 150 & $1 \cdot 0$ & None & 3 \\
\hline 7 & 53 & 174 & 1045 & 73 & 9 & 0.9 & $\begin{array}{l}\text { Prednisolone } \\
\text { (5 mg/day) }\end{array}$ & 2 \\
\hline
\end{tabular}

$\mathrm{CIC}=$ circulating immune complexes. $\mathrm{PBL}=$ peripheral blood lymphocytes. 
A reproducibility study of the assay testing 30 SLE sera on consecutive days gave a correlation coefficient of $r^{2}=0.97$.

Autologous and allogeneic mixed lymphocyte reactions. The basic method for separation of the responder $\mathrm{T}$ from stimulator non- $\mathrm{T}$ cells has been described elsewhere. ${ }^{17}$ In the cultures $3 \times 10^{6} \quad \mathrm{E}$ rosette-positive, nylon nonadherent cells $(\mathrm{E}+\mathrm{NA})$ were added to $1 \times 10^{6}$ E-rosette-negative cells which had been depleted of monocytes by adherence to plastic and inactivated with mitomycin C (E-NA). Replicate cultures were set up in the $16 \mathrm{~mm}$ wells of Costar plates (3524 Costar, Cambridge, Mass), in a total volume of $2 \mathrm{ml} \mathrm{RPM1-1640} \mathrm{(ICRF} \mathrm{Media}$ Unit) containing $5 \times 10^{-5} \mathrm{M} 2$-mercaptoethanol and $10 \%$ heat inactivated normal (NHS) or SLE serum. The plates were incubated at $37^{\circ} \mathrm{C}$ in a $5 \% \mathrm{CO}_{2}$ humidified atmosphere. $100 \mu \mathrm{l}$ of each well were sampled daily and pulsed with ${ }^{125}$ I-iododeoxyuridine $\left({ }^{125}\right.$ IUDR) as described elsewhere. ${ }^{8}$

Addition of sucrose gradient fractions to AMLRs. SLE serum was fractionated on sucrose gradients as described above. The fractions were then sterilised by filtration through millepore filters $(0.45 \mu \mathrm{m})$. Each fraction was then added to AMLR wells containing cells from normal donors in $10 \%$ NHS as described above, to give a final concentration of $10 \%$. A solution of bovine serum albumin in PBS with protein concentration equal to that of the gradient fraction with the highest protein concentration was also added as a protein control. Cultures were pulsed with ${ }^{125}$ IUDR every $24 \mathrm{~h}$ as described earlier. ${ }^{8}$

Assay for suppressor cells. AMLRs using cells from normal donors were set up in $10 \%$ heat inactivated NHS or SLE serum as described above. After 7 days viable cells were recovered over Ficoll/Hypaque, washed twice in RPMI $+10 \mathrm{mM}$ Hepes, and resuspended in RPMI 1640 containing $5 \times 10^{-5}$ 2-mertcaptoethanol and $10 \%$ heat inactivated NHS. The AMLR primed cells were added in titrating numbers to a second fresh AMLR using cells from the same normal donor. The fresh cultures were pulsed daily with IUDR as described above for a total of 7 days.

\section{Results}

Kinetics of the AMLR in normal persons and its absence in patients with $S L E$. The time kinetics of an AMLR in NHS using cells from normal and SLE donors is shown in Fig. 1. With normal cells there was a marked peak of IUDR incorporation with a maximum on day 6 . Normal E+NA cells that have been cultured but not stimulated showed no pro-

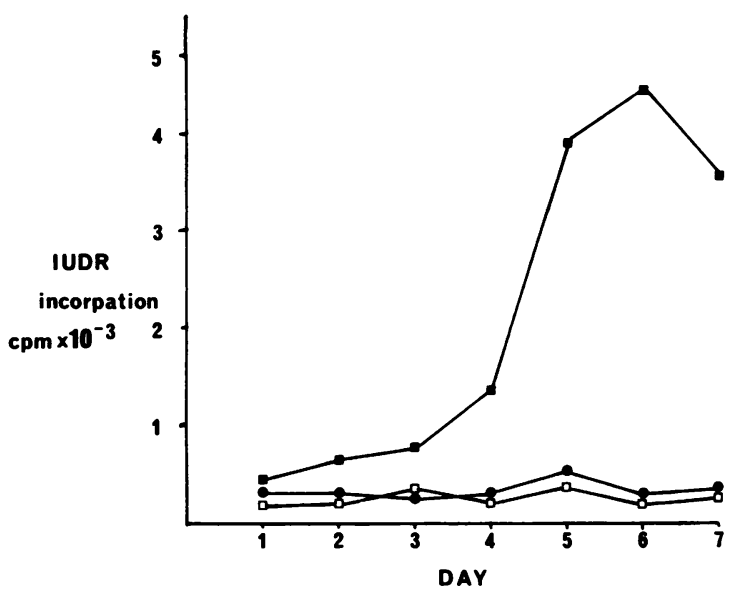

Fig. 1 The proliferative response of a primary AMLR (as measured by incorporation of $\left.{ }^{125} I U D R\right)$, using cells from a

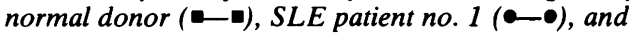
unstimulated normal $E+N A$ cells (口- $)$ ).

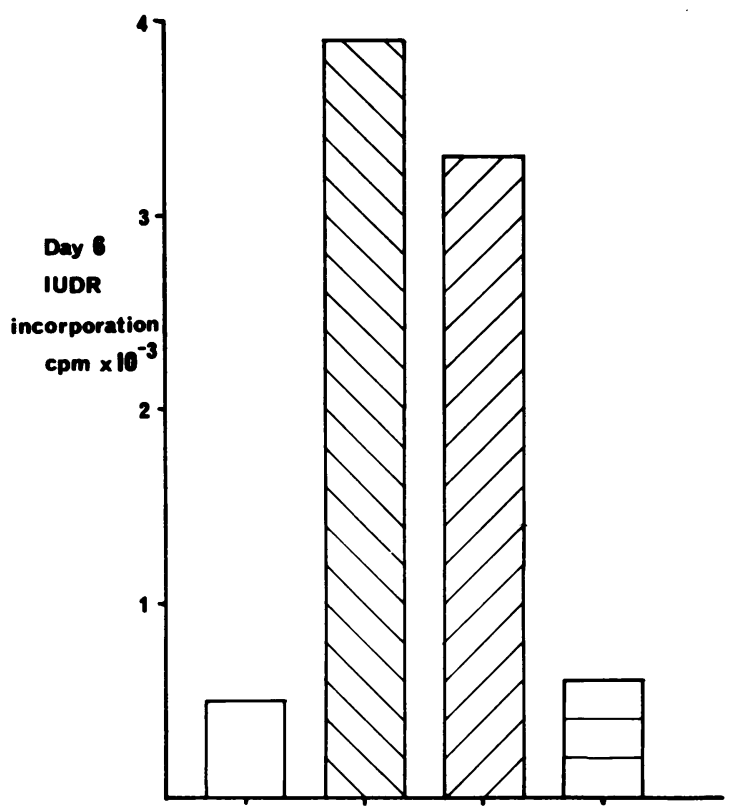

Fig. 2 Day 6 incorporation of ${ }^{125}$ IUDR of fresh unstimulated normal $E+N A$ cells $(\square)$, fresh stimulated $E+N A$ cells $(A M L R, \nabla), A M L R+5 \times 10^{5}$ cultured unstimulated autologous $E+N A$ cells $(\nabla), A M L R+5 \times 10^{5}$ $A M L R$ primed autologous $E+N A$ cells (日).

liferative response. With $\mathrm{E}+\mathrm{NA}$ cells derived from a patient with SLE and stimulated with autologous E-NA there was no response.

When the stimulated and unstimulated normal $E+N A$ cells were recovered on day 6 of an AMLR in 
NHS and added to a second fresh AMLR using cells from the same normal donor, the stimulated or AMLR primed $E+N A$ cells suppressed the primary, day 6, response in the fresh AMLR culture. The unstimulated E+NA cells did not suppress the fresh AMLR response (Fig. 2).

The effect of SLE serum on the normal AMLR and allogeneic $M L R$. The same SLE sera with differing levels of Raji cell binding material (RBM) were added to both an AMLR and an allogeneic MLR using responder E+NA cells from the same normal donor. In NHS both autologous and allogeneic responses showed marked peaks of IUDR incorporation, reaching a maximum at day 5-6. All the SLE sera essentially completely inhibited the proliferation of the responder E+NA cells in the AMLR. However, the same SLE sera reduced the response of the responder $\mathrm{E}+\mathrm{NA}$ to allogeneic stimulation but not to the same extent as in the AMLR (Fig. 3).

SLE serum was incubated overnight with or without Raji cells before addition to a normal AMLR or allogeneic MLR (Fig. 4). Whereas both autologous and allogeneic MLRs were inhibited by unabsorbed

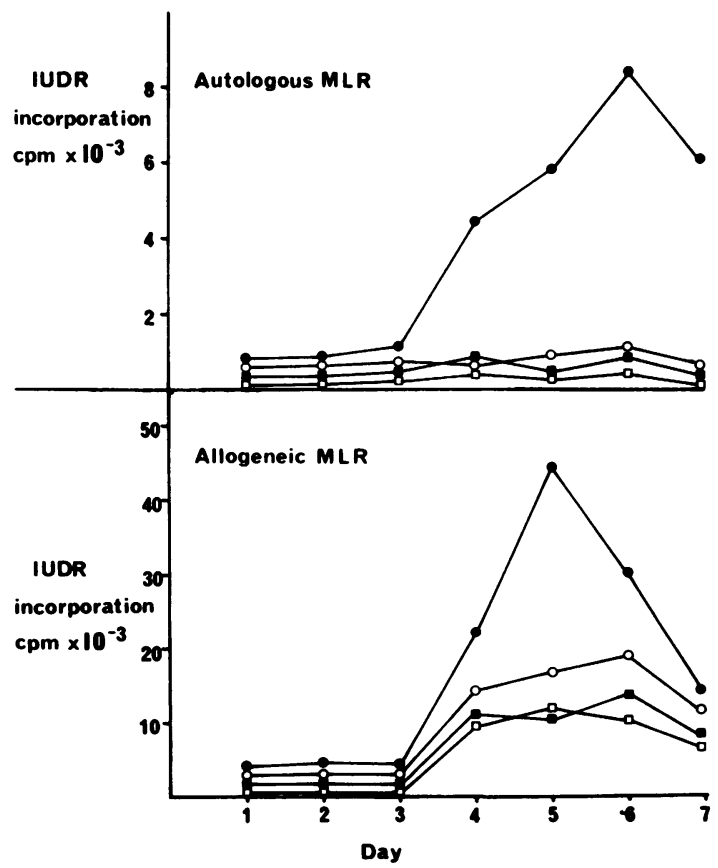

Fig. 3 Autologous and allogeneic MLRs using cells from normal donors in $10 \%$ heat inactivated $(H I) N H S(\leqslant 20$ $R B U s, \bullet \bullet), 10 \%$ (HI) SLE serum (patient no. $2,87 \cdot 5$ RBUs, 口- 口); $10 \%$ (HI) SLE serum (patient no. 3, 58.1 RBUs, =- ; $10 \%$ (HI) SLE serum (patient no. 4, 26.9 $R B U s$, ○- o).

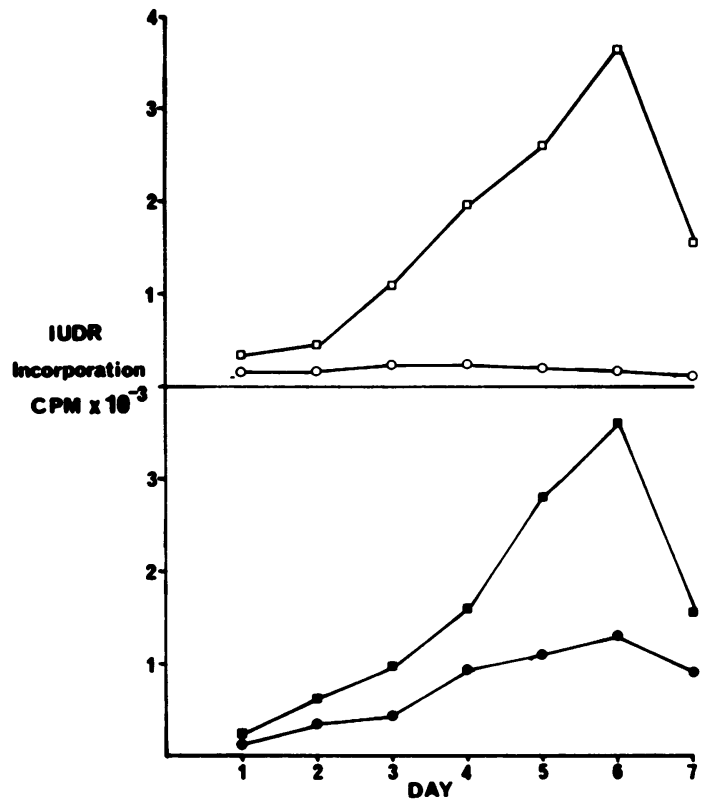

Fig. 4 Autologous MLR using cells from cells from normal donor in $10 \%$ (HI) SLE serum (patient no. 5, ○- $)$ ); $10 \%$ (HI) Raji absorbed SLE serum (patient no. 5, 느). Allogeneic MLR using cells from normal donors in $10 \%$ (HI) SLE serum (patient no. 5, -๑); $10 \%$ (HI) Raji absorbed SLE serum (patient no. 5, --).

or sham-absorbed SLE serum as described above, proliferative responses within the normal range were revealed after absorption with Raji cells. Normally the maximum incorporation of IUDR was greater in the allogeneic than the autologous MLR. In Fig. 4 the autologous and allogeneic responses which had roughly equal peak incorporation have been chosen so as to demonstrate the differential inhibitory effect of the SLE sera.

Inhibition of suppressor cell generation in the $A M L R$ in SLE serum. An AMLR with cells from a normal donor was set up in NHS and an SLE serum and pulsed daily with ${ }^{125}$ IUDR. As described above, the response in SLE serum did not show any increased incorporation over that of the cultured but unstimulated E+NA cells, while the AMLR in NHS showed significant uptake with a peak incorporation at day $6(5800 \mathrm{cpm})$. Viable cells from the unstimulated cultures and from stimulated cultures in NHS and SLE serum were recoverd by centrifugation on Ficoll/Hypaque. The recovered cells were added, in the numbers shown, to a second fresh AMLR in NHS using cells from the same normal donor. Cultures were pulsed daily with ${ }^{125}$ IUDR (Fig. 5).

In the presence of cultured but unstimulated E+NA cells the fresh AMLR showed significant 


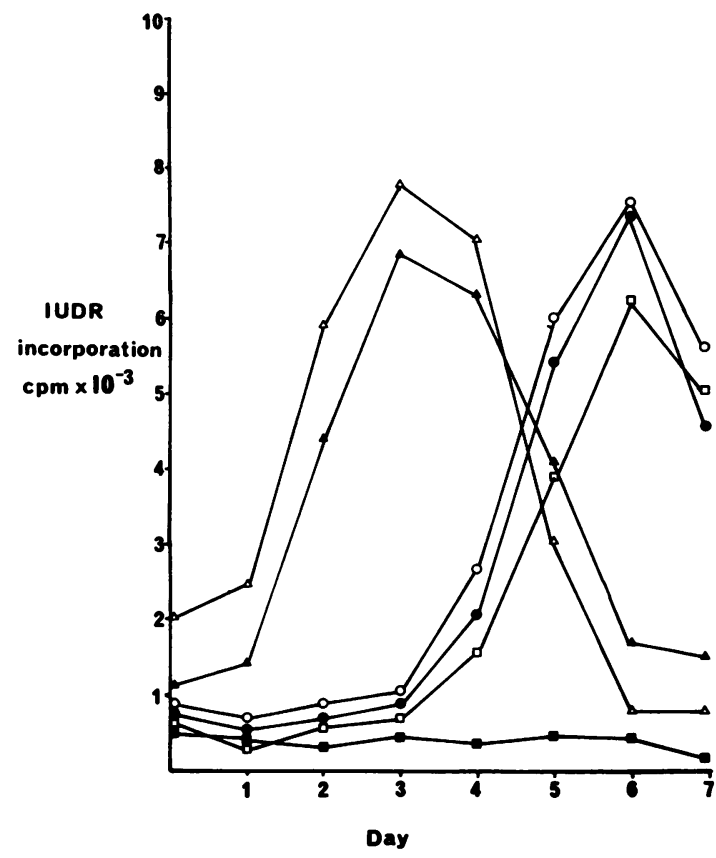

Fig. 5 Fresh AMLR in 10\% (HI) NHS using cells from normal donor $\left(\mathrm{O}_{-} \mathrm{O}\right)$. To this was added $4.5 \times 10^{5}$ autologous $A M L R$ primed $E+N A$ cells in SLE serum (patient no. 6 , $\bullet$ ); $5 \times 10^{5}$ unstimulated cultured autologous $E+N A$ cells (in NHS, 口- - ; $5 \times 10^{5}$ autologous $A M L R$ primed $E+N A$ cells (in NHS, $\triangle-\triangle$ ); $2 \times 10^{5}$ autologous $A M L R$ primed $E+N A$ cells (in NHS, $\Delta-\Delta$ ). The response of fresh unstimulated $E+N A$ is shown thus, $=-$

time-dependent incorporation reaching a maximum on day 6 . Addition of cells primed in the AMLR in NHS altered these time kinetics. Peak proliferation was now maximal at days $2-3$ and therefore occurred in an accelerated or secondary character response. There was little incorporation at day 6. Mitomycin C inactivation of the AMLR primed cells abolished the secondary or day 3 response but did not reveal a primary day 6 response (data not shown). These data suggest that $T$ cells primed in an AMLR in NHS show some secondary response to antigenic restimulation but suppress the primary response of autologous $T$ cells in a fresh AMLR.

In the presence of $\mathrm{T}$ cells recovered from the AMLR in SLE serum ${ }^{125}$ IUDR incorporation rose to reach a maximum on day 6 of the response. There was no accelerated peak on day 3 , nor was the incorporation on day 6 significantly lower than in AMLR cultures containing the same number of cultured, unstimulated $\mathrm{T}$ cells. Mitomycin $\mathrm{C}$ inactivation of AMLR primed cells was without effect on the magnitude and kinetics of the proliferative response of the fresh AMLR to which they were added (data not shown).

Sucrose gradient profile of SLE serum as measured by the Raji assay and the addition of gradient fractions to a normal $A M L R$ in NHS. In order to size the inhibitory material SLE serum was fractionated by sucrose density gradient centrifugation. Fractions from the gradient were assayed for protein, sucrose concentration, and RBM in the Raji cell radioimmunoassay. The sedimentation coefficient of indi-

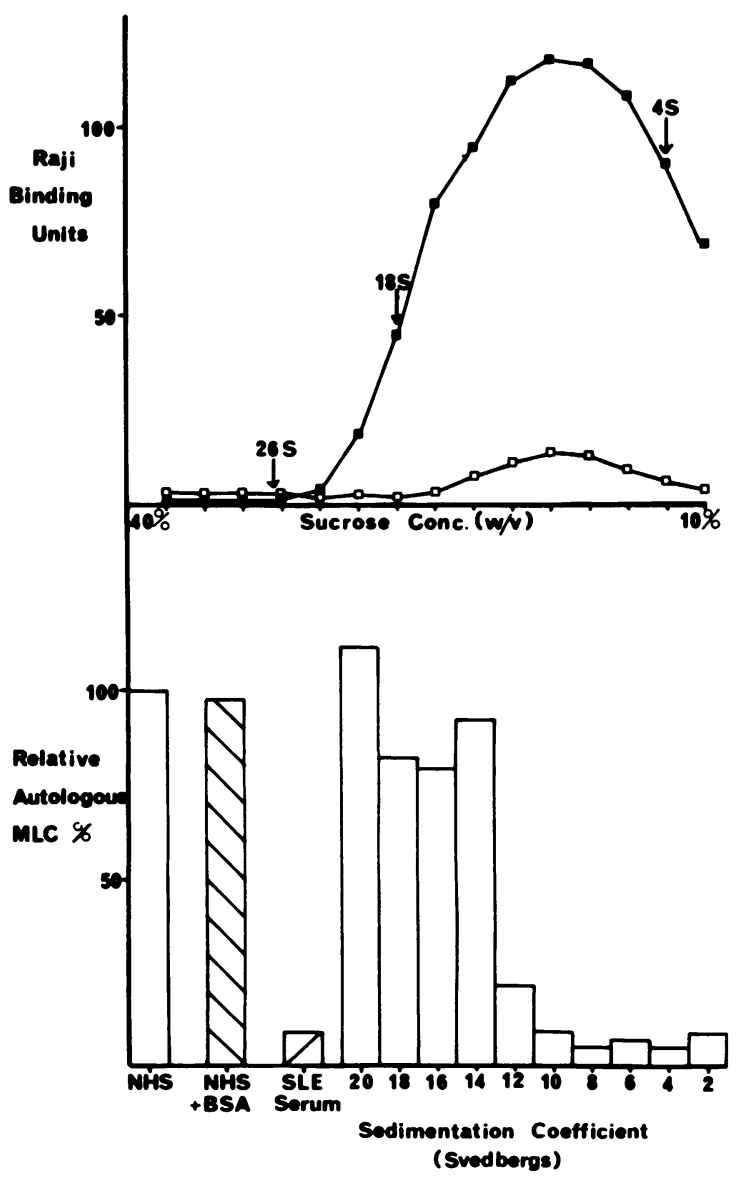

Fig. 6 (upper section). Sucrose gradient profile of $R B M$, as measured by the Raji radioimmunoassay of an SLE serum (patient no. 7, - ), and an NHS (口- ). Lower section: The addition of fractions from the same $S L E$ gradient to an $A M L R$ in NHS using cells from a normal donor. The results are expressed as a percentage of the day 6 response of the control AMLR cultures with no fractions added. BSA was used as a protein control. The day 6 response of an $A M L R$ in the same SLE serum as was run on the sucrose gradient is shown. An estimated $S$ value of the added fractions is also indicated on the horizontal axis. 
vidual fractions was calculated by reference to a standard curve of ${ }^{32} \mathrm{P}$ labelled rRNA markers of known $\mathrm{S}$ value. Fractions were then added to a normal AMLR in NHS (Fig. 6). In the top section of this figure the profile of RBM in a representative SLE serum and in an NHS is related to the calculated $S$ value of individual fractions. The peak levels of RBM were found between 7 and $19 \mathrm{~S}$ has been found in all SLE sera investigated. In some but not all the NHS fractionated in this way a peak of similar $S$ value but containing very much less RBM was evident, as in the example shown. In other NHS, however, no peak could be demonstrated.

In lower half of Fig. 6 individual fractions from the SLE serum gradient were added, at a final concentration of $10 \%$, to an AMLR using normal cells in NHS. ${ }^{125}$ IUDR incorporation was measured on day 6 and expressed as a percentage of the incorporation by the AMLR in the absence of added material. Addition of BSA or heat aggregated human gamma globulin at a protein concentration equal to that of most concentrated gradient fraction was without effect on the response. Fractions from the serum gradient with $\mathrm{S}$ values between 20 and $14 \mathrm{~S}$ similarly produced no inhibition. Serum fractions with $S$ values $\leqslant 12 S$, however, did inhibit the AMLR, while those between 2 and $10 \mathrm{~S}$ effected complete inhibition, as seen with the unfractionated SLE serum.

\section{Discussion}

This paper shows, firstly, that sera from patients with active SLE inhibit the proliferative response by $T$ cells from normal donors when stimulated by either autologous or allogeneic non-T cells. We show also that the abrogation by SLE sera of proliferation in the AMLR is associated with a lack of suppressor T cell generation.

Inhibition of the allogeneic MLR by SLE sera has already been reported. ${ }^{5}$ All the sera we have studied (total of 38 serum samples from 18 patients) inhibit the AMLR more profoundly than the allogeneic reaction. In some cases individual SLE sera, without effect in the proliferative response to alloantigen, can inhibit the AMLR completely.

These serum-mediated inhibitory effects occur independently of the treatment received by individual patients (Table 1). Sera from patients not receiving therapy can completely inhibit the AMLR. Absorption of SLE sera by Raji cells removes the inhibitory effect. Native immunoglobulin and immune complexes bind to Raji cells. ${ }^{14}$ Although in our own studies the levels of RBM and inhibitory potency in the allogeneic MLR, do not correlate $\left(r^{2}=0 \cdot 02, p>0 \cdot 05\right)$, the Raji cell radioimmunoassay, inter alia, does detect immunologically active serum factors.

When the AMLR performed in NHS, cells from normal donors proliferate to generate $\mathrm{T}$ cells which suppress proliferative and cytotoxic responses ${ }^{7}$ and inhibit polyclonal ${ }^{18}$ as well as specific antigeninduced antibody synthesis in vitro. Cells from SLE patients do not proliferate in an AMLR even when the reaction is carried out in NHS. ${ }^{19}$ SLE sera as well as inhibiting proliferation in the normal AMLR also prevents the generation of suppressor $T$ cells (Fig. 5).

Cells from SLE patients are also deficient in the suppressor response to mitogen, ${ }^{9}$ and this deficiency is exaggerated if the response is performed in autologous serum. ${ }^{11}$ SLE serum has been reported to prevent the in vitro generation of suppressor cells in normals as opposed to inhibiting the function of Ts once activated..$^{20}$ Our data may well support this observation.

Fractionation of SLE sera on sucrose gradients, with measurement of RBM in individual fractions, reveals on 8-12 S peak of material in all SLE sera investigated (Fig. 6, upper section). Addition of these fractions to an AMLR in NHS shows the inhibitory activity to have an $S$ value of $\leqslant 12 S$ (Fig. 6, lower section). Although $19 \mathrm{~S}$ IgM anti-T cell antibodies have been well described in the sera of patients with SLE, ${ }^{21}$ the fractionation study would suggest that they are not responsible for the inhibitory effects reported here. Further characterisation of the inhibitory factor is in progress.

It has been suggested that anti-T cell antibodies are responsible for the suppressor $T$ cell deficiency in NZB mice, ${ }^{22}$ a classical animal model of SLE. ${ }^{23}$ Recent evidence in the mouse, however, suggests that $\mathrm{T}$ cell defects can exist independently of any serological effect. ${ }^{24}$ Anti-T cell antibodies have also been described in human SLE, as well as cellular defects in suppressor T cell generation in the AMLR and by mitogen. The data presented here suggest that any inherent cellular dysfunction may be reinforced by serum-borne factors.

We are grateful to Dr R. L. Souhami, Dr P. C. L. Beverley, Dr D. A. Isenberg, and Dr J. Alkocer for constructive and helpful discussions. This work was supported by the Arthritis and Rheumatism Council for Research and the Emily le Rossignol fund.

\section{References}

${ }^{1}$ Levy J, Barnett E V, MacDonald N S, et al. Altered immunoglobulin metabolism in systemic lupus erythematosus and rheumatoid arthritis. $J$ Clin Invest 1970; 49: 708-15.

2 Scopelitis E, Biundo Jnr J J, Alspaugh M A. Anti-SS-A antibody and other antinuclear antibodies in systemic lupus erythematosus. Arthritis Rheum 1980; 23: 287-93. 
${ }^{3}$ Vaughan J H, Chihara T. Lymphocyte function in rheumatic disorders. Arch Intern Med 1973; 135: 1324-8.

4 Revillard J-P, Vincent C, Rivera S. Anti- $\beta 2$-microglobulin lymphocytotoxic autoantibodies in systemic lupus erythematosus. $J$ Immunol 1979; 122: 614-8.

5 Sakane T, Steinberg A D, Patton Reeves J, Green I. Studies of immune functions of patients with systemic lupus erythematosus. J Clin Invest 1979; 64: 1260-9.

${ }^{6}$ Opelz G, Kuichi M, Takasugi M, Terasaki P I. Autologous stimulation of human lymphocyte subpopulations. J Exp Med 1975; 142: 1327-33.

' Smith J B, Knowlton R P. Activation of suppressor T cells in human autologous mixed lymphocyte culture. J Immunol 1979; 123: 419-22.

${ }^{8}$ Fitzharris P, Knight R A. Generation of suppressor cells in the autologous mixed lymphocyte reaction. Clin Exp Immunol in press.

9 Sakane T, Steinberg A D, Green I. Studies of immune functions of patients with systemic lupus erythematosus. 1. Dysfunction of suppressor T-cell activity related to impaired generation of, rather than response to, suppressor cells. Arthritis Rheum 1978; 21: 657-64.

${ }^{10}$ Sakane T, Green I. Specificity and suppressor function of human T cells responsible to autologous non-T cells. J Immunol 1979; 123: 584-9.

1 Horwitz D A, Garett M A, Craig A H. Serum effects of mitogenic reactivity in subjects with systemic lupus erythematosus, rheumatoid arthritis, scleroderma. Technical considerations and lack of correlation with anti-lymphocyte antibodies. Clin Exp Immunol 1977; 27: 100-10.

${ }^{12}$ Morrow W J W, Isenberg D A, Parry H F, Snaith M L. C-reactive protein in sera from patients with systemic lupus erythematosus. $J$ Rheumatol in press.

${ }^{13}$ Poulton T A, Crowther M E, Hay F C, Nineham L J. Immune complexes in ovarian cancer. Lancet 1978; ii: 72-3.

${ }_{14}$ Theofilopolous A N, Wilson C B, Bokisch V A, Dixon F J.
Binding of soluble immune complexes to human lymphoblastoid cells. II. Use of a Raji cell to detect circulating immune complexes in animal and human sera. $J$ Exp Med 1974; 140: 1230-44.

15 Theofilopolous A N, Wilson C B, Dixon F J. The Raji cell radioimmunoassay for detecting immune complexes in human sera. J Clin Invest 1976; 57: 169-72.

${ }^{16}$ Greenwood F C, Hunter W M, Glover J S. The preparation of ${ }^{131}$ I-labelled human growth hormone of high specific radioactivity. Biochem J 1963; 89: 114-23.

17 Knight R A, Fitzharris P. Separation of spontaneous-killing effector populations by target preference. $\mathrm{Br} J$ Cancer 1980; 40: 243-51.

${ }^{18}$ Innes J B, Kuntz M M, Kim Y T, Weksler M E. Induction of suppressor activity in the autologous mixed lymphocyte reaction and culture with concanavalin-A. J Clin Invest 1979; 64: 1608-13.

19 Sakane T, Steinberg A D, Green I. Failure of the autologous mixed lymphocyte reaction between $\mathrm{T}$ and non-T cells in patients with systemic lupus erythematosus. Proc Natl Acad Sci USA 1978; 75: 3464-8.

${ }^{20}$ Sakane T, Steinberg A D, Patton Reeves J, Green I. Studies of immune functions of patients with systemic lupus erythematosus. T-cell subsets and antibodies to T-cell subsets. J Clin Invest 1979; 64: $1260-9$.

${ }^{21}$ Sakane T, Steinberg A D, Patton Reeves J, Green I. Studies of immune functions of patients with systemic lupus erythematosus. Complement-dependent immunoglobulin $\mathbf{M}$ anti-thymusderived cell antibodies preferentially inactive suppressor cells. $J$ Clin Invest 1979; 63: 954-65.

${ }^{22}$ Klassen L W, Krakauer R S, Steinberg A D. Selective loss of suppressor cell functions in New Zealand mice induced by NTA.J Immunol 1977; 119: 830-7.

${ }^{23}$ Howie J B, Helger B J. The immunology and pathology of NZB mice. Adv Immunol 1968; 9: 215.

24 Taureg J D, Raveche E S, Smathers P A, et al. T cell abnormalities in NZB mice occur independently of autoantibody production. $J$ Exp Med 1981; 153: 221-34. 